\title{
Fungi dominate denitrification when Chinese milk vetch green manure is used in paddy soil
}

\author{
Minghe Jiang, Luan Zhang*, Ming Liu, Han Qiu, Shungui Zhou
}

Fujian Provincial Key Laboratory of Soil Environmental Health and Regulation, College of Resources and Environment, Fujian Agriculture and Forestry University, Fuzhou 350002, China

H I G H L I G H T S

-We evaluated effects of fungi on $\mathrm{N}_{2} \mathrm{O}$ emission in Chinese milk vetch-containing soils.

- Fungi to contributed to soil $\mathrm{N}_{2} \mathrm{O}$ production in CMV-amended soils.

- Fungi accounted for $56 \%$ of $\mathrm{N}_{2} \mathrm{O}$ emission in CMV-amended soils.

- Fungi may be important contributors to $\mathrm{N}_{2} \mathrm{O}$ production in CMV-amended soils.

\section{ARTICLE INFO}

Article history:

Received April 29, 2020

Revised September 4, 2020

Accepted September 21, 2020

\section{Keywords:}

Fungi

Bacteria

Nitrous oxide

Chinese milk vetch

Paddy soil
GRAPHICAL ABSTRACT

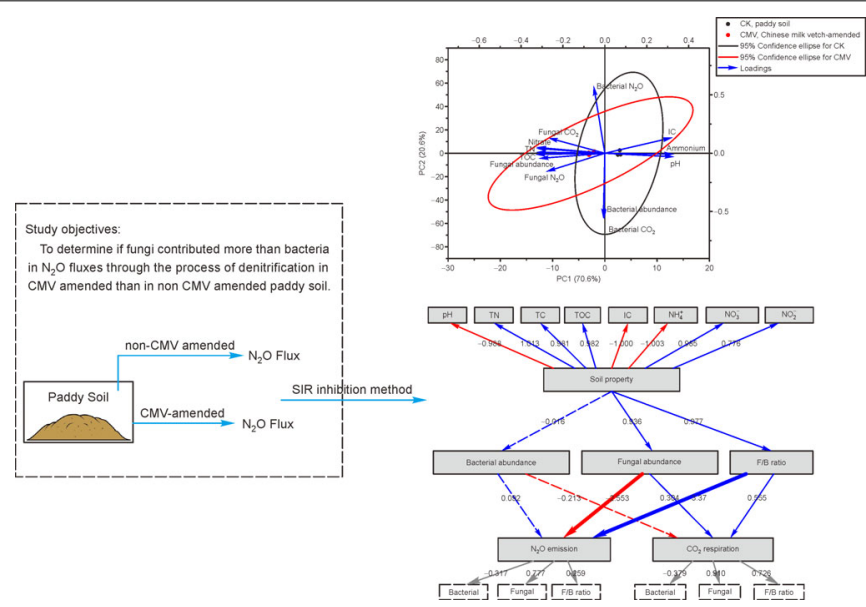

A B S T R A C T

Fungi play an important role in soil nitrous oxide $\left(\mathrm{N}_{2} \mathrm{O}\right)$ emission in many agricultural soil systems. However, the effect of fungi on $\mathrm{N}_{2} \mathrm{O}$ emission in Chinese milk vetch (CMV)-containing soils has not been examined sufficiently. This study investigated the contribution of bacteria and fungi to soil $\mathrm{N}_{2} \mathrm{O}$ emission in CMV-amended soils. We compared soils from an experimental field in the Fujian Academy of Agricultural Sciences that had been treated with $30000 \mathrm{~kg}$ of CMV per $667 \mathrm{~m}^{2}$ per year with one that was not treated with CMV. We incubated soil using cycloheximide and streptomycin to differentiate fungal and bacterial $\mathrm{N}_{2} \mathrm{O}$ emissions, respectively. Quantitative PCR (qPCR) was performed to investigate bacterial and fungal abundances in the two agricultural soil ecosystems. The contribution of fungi to soil $\mathrm{N}_{2} \mathrm{O}$ emission in $\mathrm{CMV}$-amended soils was greater than that in nonCMV-amended paddy soils, with fungi accounting for more than $56 \%$ of the emissions in CMVamended soils. Quantitative PCR showed that the ratio of the internal transcribed spacer to $16 \mathrm{~S}$ rDNA was significantly higher in CMV-amended soils than in non-CMV-amended paddy soils. Furthermore, soil properties, such as $\mathrm{pH}(P<0.05)$ and $\mathrm{NH}_{4}{ }^{+}$concentration $(P<0.05)$, significantly and negatively affected $\mathrm{N}_{2} \mathrm{O}$ emission by fungi in soil, whereas the total organic carbon $(P<0.05)$ and $\mathrm{NO}_{3}{ }^{-}$concentration $(P<0.05)$ showed significant positive effects. Fungi may be important contributors to $\mathrm{N}_{2} \mathrm{O}$ production in $\mathrm{CMV}$-amended soils, which may create challenges for mitigating $\mathrm{N}_{2} \mathrm{O}$ production.

(C) Higher Education Press 2020

* Corresponding author

E-mail address: sarcina@126.com (L. Zhang) 


\section{Introduction}

Nitrous oxide $\left(\mathrm{N}_{2} \mathrm{O}\right)$, which is the third most prevalent anthropogenic greenhouse gas, is present at 310-fold higher levels than carbon dioxide, and it has the potential to cause global warming (Lassey and Harvey, 2007; Davidson and Kanter, 2014). Moreover, it is the predominant ozoneremoving substrate (Ravishankara et al., 2009) and a major form of nitrogen pollution (Davidson, 1991). Agricultural soils are essential sources of global $\mathrm{N}_{2} \mathrm{O}$ production (Ravishankara et al., 2009; Hoben et al., 2011): $\mathrm{N}_{2} \mathrm{O}$ is generated primarily by microorganisms in the soil, such as nitrifiers and denitrifiers (Ai et al., 2017). Denitrification is the dominant pathway contributing to soil $\mathrm{N}_{2} \mathrm{O}$ emission and can contribute up to $90 \%$ of the total soil $\mathrm{N}_{2} \mathrm{O}$ production in $75 \%$ of the water-filled pore space (Khalil and Baggs, 2005).

Bacteria were the first organisms found to produce $\mathrm{N}_{2} \mathrm{O}$, and the production of $\mathrm{N}_{2} \mathrm{O}$ was initially thought to be limited to eubacteria (Zumft, 1997). However, recent studies have shown that fungi can contribute substantially to soil $\mathrm{N}_{2} \mathrm{O}$ emissions in diverse soil systems (Yanai et al., 2007; Jirout et al., 2013; Huang et al., 2017). Generally, in the denitrification pathway, bacteria reduce $\mathrm{NO}_{3}{ }^{-}$consecutively to $\mathrm{NO}_{2}{ }^{-}$, $\mathrm{NO}$ (nitric oxide), $\mathrm{N}_{2} \mathrm{O}$, and $\mathrm{N}_{2}$, whereas fungi lack $\mathrm{N}_{2} \mathrm{O}$ reductase, and thus, the reaction terminates with $\mathrm{N}_{2} \mathrm{O}$ (Thomson et al., 2012). This lack of $\mathrm{N}_{2} \mathrm{O}$ reductase suggests that fungi play a more critical role in soil $\mathrm{N}_{2} \mathrm{O}$ emission. In situ studies have shown that fungi contribute more than $50 \%$ to total soil $\mathrm{N}_{2} \mathrm{O}$ emissions (Mothapo et al., 2015). Diverse abiotic factors influence fungal $\mathrm{N}_{2} \mathrm{O}$ production. For example, a low soil $\mathrm{pH}$ is beneficial when fungi contribute the most to denitrification (Huang et al., 2017). In contrast to bacterial denitrification, fungi perform better under anoxic conditions (Mothapo et al., 2013; Huang et al., 2017). The requirement for $\mathrm{O}_{2}$ by fungi is determined by the type of $\mathrm{N}$, which is high for $\mathrm{NO}_{3}{ }^{-}$and low for $\mathrm{NO}_{2}{ }^{-}$(Mothapo et al., 2013). Moreover, the quality of organic substrates can influence the development and activity of fungi and bacteria (Chen et al., 2015).

Chinese milk vetch (CMV) is a widespread perennial legume that is often utilized as a feed crop worldwide. It is also a high-quality green manure that is used in south-east China (Yang et al., 2014), where CMV biomass is plowed into paddy soil (Xie et al., 2018). Simple and complex compounds are found in plant materials (Hadas et al., 2004), but their proportions differ in various green manures, which can cause soil fungi and bacteria to grow at different rates (Zhao et al., 2019). Previous studies have shown that low $\mathrm{C}: \mathrm{N}$ ratios in plant materials lead to a high bacteria to fungi ratio, whereas fungal dominance occurs in the presence of plant materials with a high C:N ratio (Poll et al., 2008; Chen et al., 2015).

We evaluated samples of paddy soil from Fuzhou containing grazed green manure CMV to assess whether fungi contributed more than bacteria to $\mathrm{N}_{2} \mathrm{O}$ fluxes through the process of denitrification. This study determined whether 1) the green manure CMV benefited the growth of fungi over bacteria, causing fungi to release most of the $\mathrm{N}_{2} \mathrm{O}$ found in the soil, and 2) fungi or bacteria dominated $\mathrm{N}_{2} \mathrm{O}$ production in soil samples with different $\mathrm{pH}$ and total organic carbon (TOC) and nitrogen concentrations.

\section{Materials and methods}

\subsection{Soil sampling}

Paddy soil was sampled at a depth of 0-20 cm at the Red Soil Fertility and Ecological Environment of Field Observation Station at Fuzhou Station $\left(119^{\circ} 04^{\prime} 10^{\prime \prime} \mathrm{E}, 26^{\circ} 13^{\prime} 31^{\prime \prime} \mathrm{N}\right)$. Chinese milk vetch was harvested during full-bloom, cut into $2-\mathrm{cm}$ pieces, and blended together. Next, the CMV samples were buried at a depth of $10 \mathrm{~cm}$, with nearly $30000 \mathrm{~kg}$ of CMV per $667 \mathrm{~m}^{2}$ incorporated into soil. Then, soil samples of at least $50 \mathrm{~g}$ were randomly collected from five sites and stored in sterile valve bags. Paddy soil samples from the five sites were mixed together. Then, they were air-dried, sieved through a $1-\mathrm{mm}$ mesh sieve, and stored at $-20^{\circ} \mathrm{C}$ until analysis. Before the experiement, the soil had a $\mathrm{pH}$ of 4.94 , and there was $25 \mathrm{~g} \mathrm{~kg}^{-1}$ organic matter, $124.4 \mathrm{mg} \mathrm{kg}^{-1}$ available $\mathrm{N}$, $21.3 \mathrm{mg} \mathrm{kg}^{-1}$ available $\mathrm{P}$, and $101.2 \mathrm{mg} \mathrm{kg}^{-1}$ available $\mathrm{K}$. The characteristics of the experimentally supplied CMV were $59.27 \%$ organic carbon, $2.6 \%$ total $\mathrm{N}, 0.3 \%$ total $\mathrm{P}, 2.5 \%$ total $\mathrm{K}$, and $12.6 \%$ dry matter.

\subsection{Incubation experiments}

Soil samples from paddy soil (CK) and paddy soil amended with CMV (12 g dry soil) were placed into 100-mL anaerobic vials. Then, $6 \mathrm{~mL}$ of solution containing $\mathrm{KNO}_{3}\left(50 \mu \mathrm{g} \mathrm{NO}_{3}{ }^{-}\right.$ $\mathrm{N} \mathrm{g}^{-1}$ dry soil) and glucose $\left(0.5 \mathrm{mg} \mathrm{C} \mathrm{g}^{-1}\right.$ soil) was added. Cycloheximide and streptomycin were added to inhibit the activities of fungi and bacteria and investigate the fungal and bacterial contribution to soil $\mathrm{N}_{2} \mathrm{O}$ production (Anderson and Domsch, 1973), respectively. Four antibiotic treatments were performed in triplicate: (1) an antibiotic-free treatment as a control, with no antibiotic added; (2) only streptomycin, with $3.0 \mathrm{mg}$ streptomycin added $\mathrm{g}^{-1}$ soil; (3) only cycloheximide, with $5.0 \mathrm{mg}$ cycloheximide added $\mathrm{g}^{-1}$ soil; and (4) both antibiotics, with streptomycin added at $3.0 \mathrm{mg} \mathrm{g}^{-1}$ and cycloheximide added at $5.0 \mathrm{mg} \mathrm{g}^{-1}$. In previous studies, these antibiotic concentrations had a limited effect on nontarget organisms (Laughlin and Stevens, 2002). Next, $2 \mathrm{~mL}$ of deionized water was used to dissolve the chemicals, which were added to anaerobic vials with soil to prepare an $80 \%$ water-filled pore space. The headspace of the soil slurries was flushed with ultra-high-purity $\mathrm{He}$. Then the soils were incubated at $25^{\circ} \mathrm{C}$ in an anaerobic jar for two days to stabilize soil microbial activity, followed by incubation at $25^{\circ} \mathrm{C}$ for the next 28 days. The physicochemical properties, including total nitrogen (TN), total carbon (TC), inorganic carbon (IC), $\mathrm{NH}_{4}{ }^{+}-$ $\mathrm{N}, \mathrm{NO}_{3}{ }^{-}$, and $\mathrm{NO}_{2}{ }^{-}$, of the soil sample extracts were determined following Zhang et al. (2019). 


\section{$2.3 \mathrm{~N}_{2} \mathrm{O}$ and $\mathrm{CO}_{2}$ sampling and measurement}

The gas concentration of $\mathrm{N}_{2} \mathrm{O}$ was determined at 2,14 , and 28 days using a robot system with an electron detector (Agilent Technologies, Santa Clara, CA, USA). Concentrations of $\mathrm{CO}_{2}$ were determined on the same days using an infrared gas analyzer (Li-COR, Lincoln, NE, USA). The contribution of fungi to soil $\mathrm{N}_{2} \mathrm{O}$ (or $\mathrm{CO}_{2}$ ) emissions was determined following Chen et al. (2015). The fungal contribution to soil $\mathrm{N}_{2} \mathrm{O}$ emission or $\mathrm{CO}_{2}$ fluxes was estimated by using the formula:

$$
\frac{100 \times(A-B)}{A-D},
$$

where $A$ represents $\mathrm{N}_{2} \mathrm{O}$ emissions or $\mathrm{CO}_{2}$ fluxes in the antibiotic-free control and $B$ and $D$ represent soil $\mathrm{N}_{2} \mathrm{O}$ (or $\mathrm{CO}_{2}$ ) emission in soil amended with cycloheximide and soil with both streptomycin and cycloheximide, respectively. The equation can also be used to calculate the contribution of bacteria by replacing $B$ with $\mathrm{N}_{2} \mathrm{O}$ (or $\mathrm{CO}_{2}$ ) emission in soil amended with streptomycin. In addition, the inhibitor additivity ratio (IAR) was utilized to assess whether the antibiotics exerted non-target effects as described by Beare et al. (1990) and Chen et al. (2015).

\subsection{Abundance of bacteria and fungi}

At 2, 12, and 28 days, soils were sampled from an antibioticfree microcosm, and gas analysis was conducted. In addition, a $0.5 \mathrm{~g}$ soil sample was weighed and used for genomic DNA extraction with the FastDNA ${ }^{\circledR}$ SPIN Kit for Soil (MP Biomedicals, Santa Ana, CA, USA) following the manufacturer's instructions. The quality and size of soil DNA was checked using a NanoDrop 2000 spectrophotometer (Thermo Fisher Scientific, Waltham, MA, USA).

The abundance of bacteria and fungi was determined in triplicate using quantitative polymerase chain reaction (qPCR) using a LightCycler 480 (Roche, Basel, Switzerland). The gene copy numbers of the $16 \mathrm{~S}$ rDNA and internal transcribed spacer (ITS) region of rDNA were determined. The primer sequences used for bacteria were 519F 5'-CCTACGGGAGGCAGCAG-3' and 907R 5'- TTACCGCGGCTGCTGGCAC-3', and a specific amplification procedure was used: $2 \mathrm{~min}$ at $95^{\circ} \mathrm{C}, 40$ cycles of PCR for $15 \mathrm{~s}$ at $95^{\circ} \mathrm{C}$, and $1 \mathrm{~min}$ at $55^{\circ} \mathrm{C}$. A final melting curve step was performed to complete the procedure. The primer sequences used for the fungi were 5.8S 5'-CGCTGCGTTCTTCATCG-3' and ITS-1F 5'TCCGTAGGTGAACCTGCGG-3', and amplification was performed as follows: 2 min at $95^{\circ} \mathrm{C}, 40$ cycles of PCR for $15 \mathrm{~s}$ at $95^{\circ} \mathrm{C}$, and $1 \mathrm{~min}$ at $58^{\circ} \mathrm{C}$. A melting curve step was also performed. Each $50-\mu \mathrm{L}$ reaction contained $25 \mu \mathrm{L}$ of SYBR Green $(2 \times)$ PCR Master Mix (Life Technologies, Carlsbad, CA, USA), $1 \mu \mathrm{L}$ of each primer, and $5 \mu \mathrm{L}$ of the DNA template. The efficiency values of all amplification reactions were approximately $90 \%-100 \%$, and the $\mathrm{R}^{2}$ values of the standard curves were greater than 0.99 .

\subsection{Data analysis}

Analysis of variance (ANOVA) was conducted using SPSS 16.0 software (SPSS, Inc., Chicago, IL, USA) to evaluate significant differences $(P \leqslant 0.05)$ in soil $\mathrm{CO}_{2}$ and $\mathrm{N}_{2} \mathrm{O}$ emission velocities and $\mathrm{CO}_{2}$ respiration among the four antibiotic treatments in $\mathrm{CK}$ and $\mathrm{CMV}$-amended soils. Additionally, ANOVA was used to compare the relative contribution of fungi and bacteria to soil $\mathrm{N}_{2} \mathrm{O}$ emission and $\mathrm{CO}_{2}$ respiration between the two treatments. Principal coordinates analysis was performed using originPro 2018 software using Principal Component Analysis v 1.0. Path analysis was performed using SmartPLS 3 software (SmartPLS GmbH, Germany), which is a statistical method used to demonstrate cause and effect relationships between observed and latent variables. The maximum iterations were set to 300 and missing data were deleted pairwise. The bootstrapping routine was set to a 0.05 probability level and 500 bootstraps were used to validate the estimates of the path coefficients.

\section{Results}

\subsection{Effect of Chinese milk vetch on soil characteristics}

As shown in Table 1, most soil properties, including TN, TC, TOC, $\mathrm{NH}_{4}{ }^{+}-\mathrm{N}, \mathrm{NO}_{3}{ }^{-}-\mathrm{N}$, and $\mathrm{NO}_{2}{ }^{-}-\mathrm{N}$ levels, were significantly different between $\mathrm{CK}$ and $\mathrm{CMV}$-amended soils. Particularly, the levels of TN, TC, TOC, $\mathrm{NO}_{3}{ }^{-}-\mathrm{N}$, and $\mathrm{NO}_{2}{ }^{-} \mathrm{N}$ in CMVamended soils were significantly higher $(P<0.05)$ than those in $\mathrm{CK}$ soils. In contrast, the concentration of $\mathrm{NH}_{4}{ }^{+}-\mathrm{N}$ in $\mathrm{CMV}-$ amended soils was significantly lower $(P<0.05)$ than that in CK soils. The $\mathrm{pH}$ of CMV soils was lower than that in CK soils, but the difference was not significant. There was no significant difference in the IC between the two treatments (Table 1), indicating that the addition of CMV altered the characteristics of the paddy soil.

Table 1 Physicochemical properties of two types of paddy soil before incubation of the microcosms.

\begin{tabular}{lll}
\hline Treatment & $\mathrm{CK}$ & $\mathrm{CMV}$ \\
\hline $\mathrm{pH}$ & $4.98 \pm 0.01^{\mathrm{a}}$ & $4.37 \pm 0.02^{\mathrm{b}}$ \\
$\mathrm{TN}\left(\mu \mathrm{g} \mathrm{g}^{-1}\right)$ & $0.93 \pm 0.06^{\mathrm{b}}$ & $2.01 \pm 0.09^{\mathrm{a}}$ \\
$\mathrm{TC}\left(\mathrm{mg} \mathrm{g}^{-1}\right)$ & $13.53 \pm 0.44^{\mathrm{b}}$ & $20.02 \pm 1.01^{\mathrm{a}}$ \\
$\mathrm{IC}\left(\mu \mathrm{g} \mathrm{g}^{-1}\right)$ & $1.37 \pm 0.02^{\mathrm{a}}$ & $1.27 \pm 0.03^{\mathrm{b}}$ \\
$\mathrm{TOC}\left(\mu \mathrm{g} \mathrm{g}^{-1}\right)$ & $12.16 \pm 0.46^{\mathrm{b}}$ & $18.75 \pm 1.03^{\mathrm{a}}$ \\
$\mathrm{NH}_{4}{ }^{+}\left(\mu \mathrm{g} \mathrm{g}^{-1}\right)$ & $36.70 \pm 0.75^{\mathrm{a}}$ & $23.73 \pm 0.48^{\mathrm{b}}$ \\
$\mathrm{NO}_{3}{ }^{-}\left(\mu \mathrm{g} \mathrm{g}^{-1}\right)$ & $1.54 \pm 0.14^{\mathrm{b}}$ & $26.45 \pm 1.07^{\mathrm{a}}$ \\
$\mathrm{NO}_{2}^{-}\left(\mathrm{ng} \mathrm{g}^{-1}\right)$ & $7.33 \pm 5.03^{\mathrm{b}}$ & $107.33 \pm 50.96^{\mathrm{a}}$ \\
\hline
\end{tabular}

Treatments: CK, control paddy soil; CMV, paddy soil amended with Chinese milk vetch; Data are shown as the mean \pm standard error of the mean. TN: total nitrogen; TC: total carbon; IC: inorganic carbon; TOC: total organic carbon. 


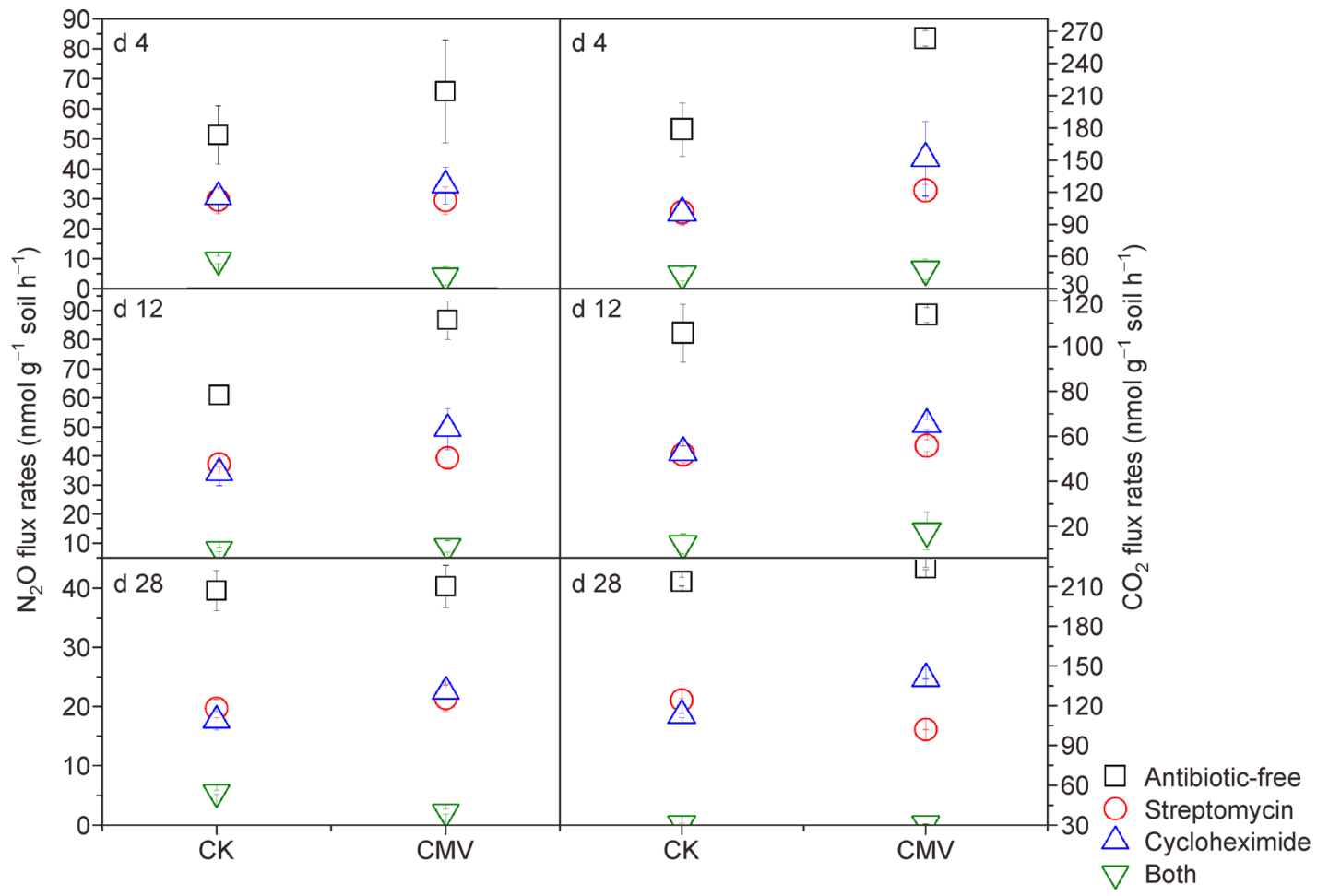

Fig. 1 Effects of treatments of antibiotics on soil $\mathrm{N}_{2} \mathrm{O}$ or $\mathrm{CO}_{2}$ flux rates at 4, 12, and 28 days of soil sample incubation. Data are presented as the mean values with standard errors $(n \geqslant 3)$.

3.2 Contributions of bacteria and fungi to soil $\mathrm{N}_{2} \mathrm{O}$ and $\mathrm{CO}_{2}$ fluxes

Bacteria and fungi contributed differently to soil $\mathrm{N}_{2} \mathrm{O}$ fluxes in $\mathrm{CK}$ and $\mathrm{CMV}$-amended soils. When there was sufficient $\mathrm{KNO}_{3}$ and glucose, the added antibiotics exerted significant inhibitory effects $(P<0.05)$ on the $\mathrm{N}_{2} \mathrm{O}$ and $\mathrm{CO}_{2}$ emission rate in the soils (Fig. 1). In CK soils, bacteria and fungi did not significantly influence soil $\mathrm{N}_{2} \mathrm{O}$ fluxes (Fig. 2A, 2B). In contrast, the fungi contributed significantly more to $\mathrm{N}_{2} \mathrm{O}$ production in CMV-amended soil than in paddy soil $(P<0.05)$ (Fig. 2B). However, the fungal-to-bacterial contribution ratios were higher in CMV-amended soil than in paddy soil $(P<0.05)$ (Fig. 2C). The fungal-to-bacterial contribution ratios for $\mathrm{CO}_{2}$ were also greater in $\mathrm{CMV}$-amended soil than in paddy soil $(P<0.05)$ (Fig. 2C). The inhibitor additivity (IAR) values were approximately 1.0 (Fig. 2D). The data showed that both streptomycin and cycloheximide effectively inhibited the development and activity of fungi and bacteria, but these antibiotics did not strongly influence non-target organisms.

\subsection{Effect of Chinese milk vetch on microbial abundance}

Both bacterial and fungal abundance had increased by day 28 $(P<0.05)$. The fungal abundance in CMV-amended soil was significantly higher than in paddy soil on day $28(P<0.05)$, resulting in a high fungi-to-bacteria ratio (Fig. 3 ). The fungalto-bacterial ratios in CMV-amended soils were greater than those in paddy soils on days $4(P<0.05), 12(P<0.05)$, and 28 $(P<0.001)$.

3.4 Correlation between soil properties and fungal $\mathrm{N}_{2} \mathrm{O}$ emission

The $\mathrm{pH}, \mathrm{NH}_{4}{ }^{+}-\mathrm{N}$ concentration, and IC were negatively related to fungal $\mathrm{N}_{2} \mathrm{O}$ production and fungal $\mathrm{CO}_{2}$ respiration. However, the TN, TOC, and nitrate concentration and fungi abundance were positively related to fungal $\mathrm{N}_{2} \mathrm{O}$ production and fungal $\mathrm{CO}_{2}$ respiration (Fig. 4). The soil samples from $\mathrm{CK}$ (PC1, Fig. 4) were distinct from those subjected to CMV treatments (PC2), and the sum of PC1 and PC2 accounted for $91.2 \%$ of the variation in all parameters determined in this experiment (Fig. 4).

Path analysis showed that fungal abundance, and particularly the fungi-to-bacteria ratio, rather than the bacterial abundance significantly affected $(P<0.05)$ soil $\mathrm{N}_{2} \mathrm{O}$ emissions. Soil properties positively affected the fungal abundance and F/B ratio (Fig. 5). Soil characteristics, such as $\mathrm{pH}, \mathrm{TN}, \mathrm{TC}$, $\mathrm{NH}_{4}{ }^{+}$, and $\mathrm{NO}_{3}^{-}$(Fig. 5) showed significant differences, indicating that $\mathrm{CMV}$ altered the soil properties.

\section{Discussion}

Through selective inhibition by antibiotics, the fungi in CMVamended soil showed a high potential to contribute to soil $\mathrm{N}_{2} \mathrm{O}$ production (Fig. 1). This is in agreement with the results of a 


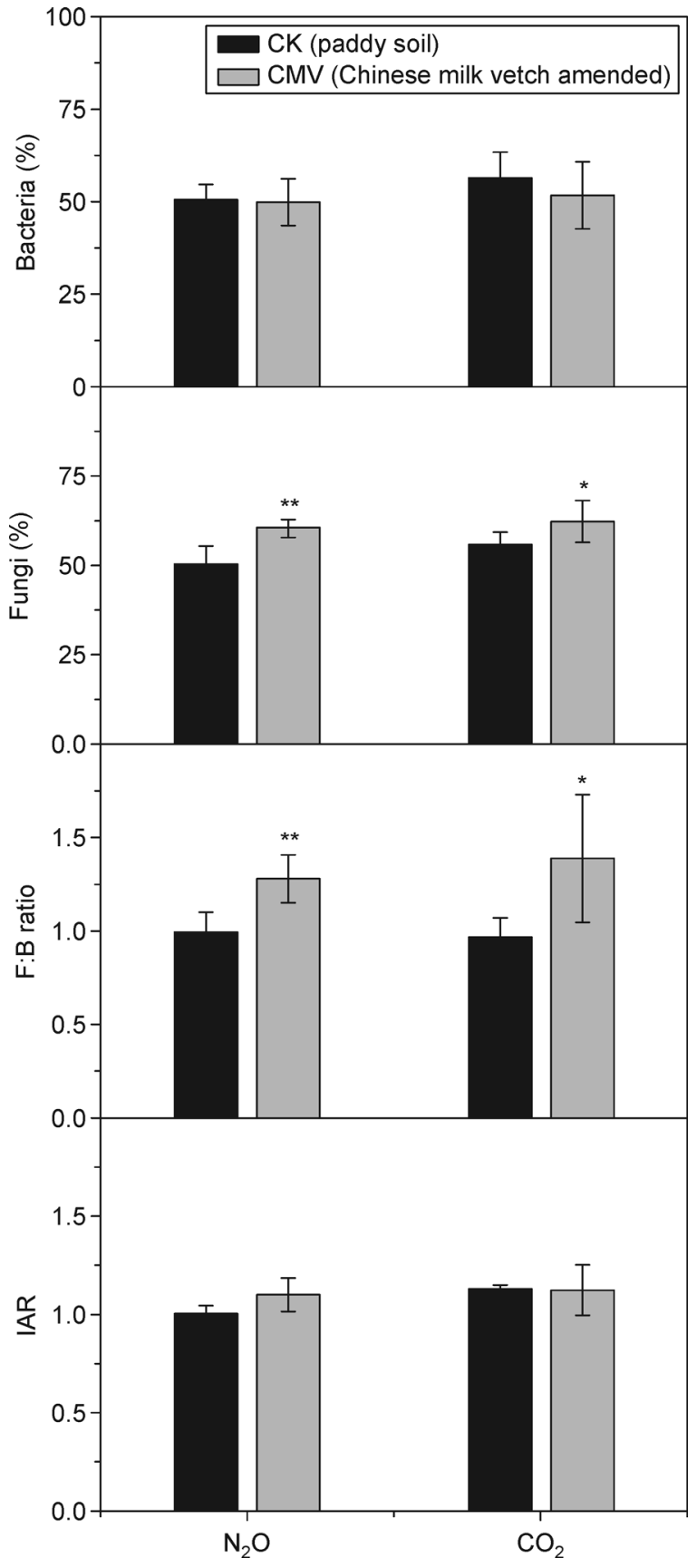

Fig. 2 Effects of different antibiotic treatments on the proportions of fungal (fungi \%) or bacterial (bacteria \%) contributions to gas emissions, fungal-to-bacterial contribution ratios (F: B), and inhibitor additivity (IAR). Error bars represent standard error for $n$ $=9$ (i.e., replicates $\times 3$ sampling times). * and ${ }^{* *}$ indicate significant differences between the two treatments at $\alpha=0.05$ and 0.001 , respectively.

previous study that showed that complex substrates are more beneficial for increasing fungal $\mathrm{N}_{2} \mathrm{O}$ emissions (Chen et al., 2015). During the experiment, this effect was observed at nearly all sampling times. More than $56 \%$ of $\mathrm{N}_{2} \mathrm{O}$ production in the soil was attributable to fungal activity, and the contribution

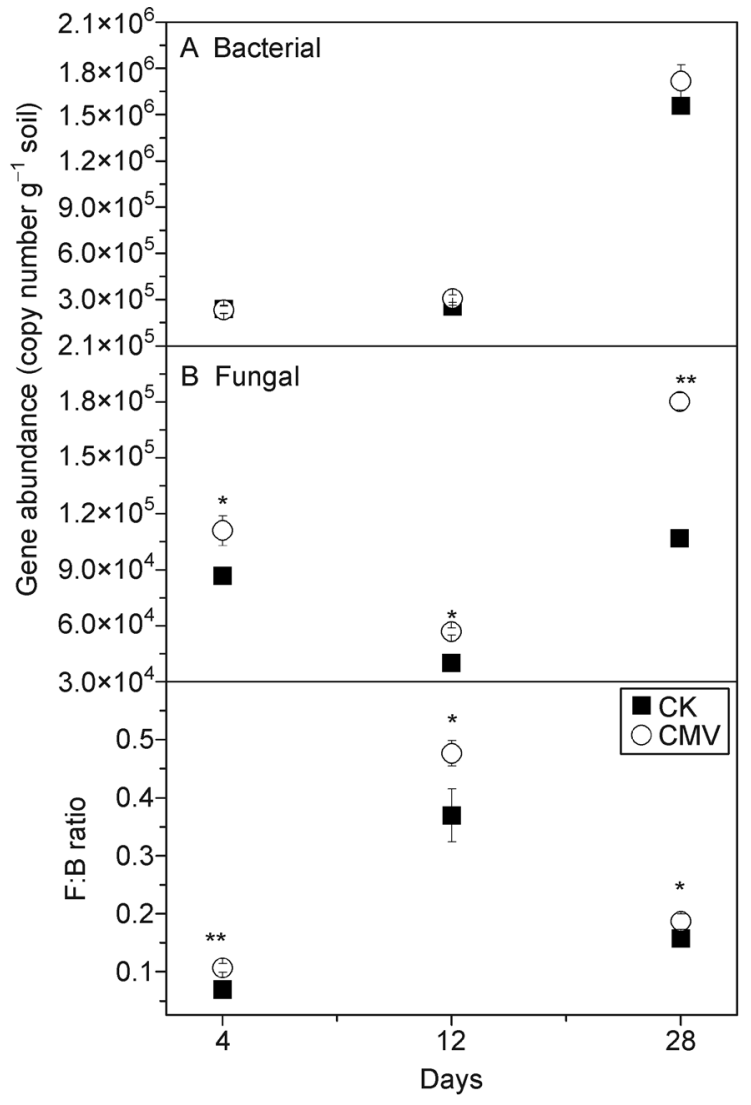

Fig. 3 Gene copy numbers of the $16 \mathrm{~S}$ rDNA and ITS region of rDNA and ratios of ITS to 16S rDNA copy number. Error bars represent the standard error for $n=3 .{ }^{*}$ and ${ }^{* *}$ indicate significant differences between the two treatments at $\alpha=0.05$ and 0.001 , respectively.

of fungi to soil $\mathrm{N}_{2} \mathrm{O}$ production was equivalent to or greater than the bacterial influx in CMV-amended soils (Fig. 1).

4.1 Soil elements controlling fungal contribution to soil $\mathrm{N}_{2} \mathrm{O}$ emission

The CMV-amended soils showed differences in soil properties, such as $\mathrm{pH}$. Complex factors function to lower the soil $\mathrm{pH}$ following the addition of CMV. The degree of decrease and increase in soil $\mathrm{pH}$ depends on the type of plant material, soil properties, and physicochemical properties (Wang et al., 2013). Previous studies have demonstrated that the primary elements influencing the $\mathrm{pH}$ of soil amended with plants are organic anions, basic cations, and nitrogen content (Bolan et al., 1991; Noble et al., 1996; Xu et al., 2006a, 2006b). The addition of legume roots (subterranean clover) was shown to slightly decrease the soil $\mathrm{pH}$ (Tang and Yu, 1999). Legume roots are often regarded as an indispensable contributor to total $\mathrm{N}$ in the plant system (McNeill et al., 1997), and soil pH decreases when nitrate ions leach out from a soil layer (Dolling, 1995; Xu and Coventry, 2003). Numerous studies have shown that soil $\mathrm{pH}$ strongly regulates the rate of denitrification (Baggs et al., 2010; Hu et al., 2013), and fungi 


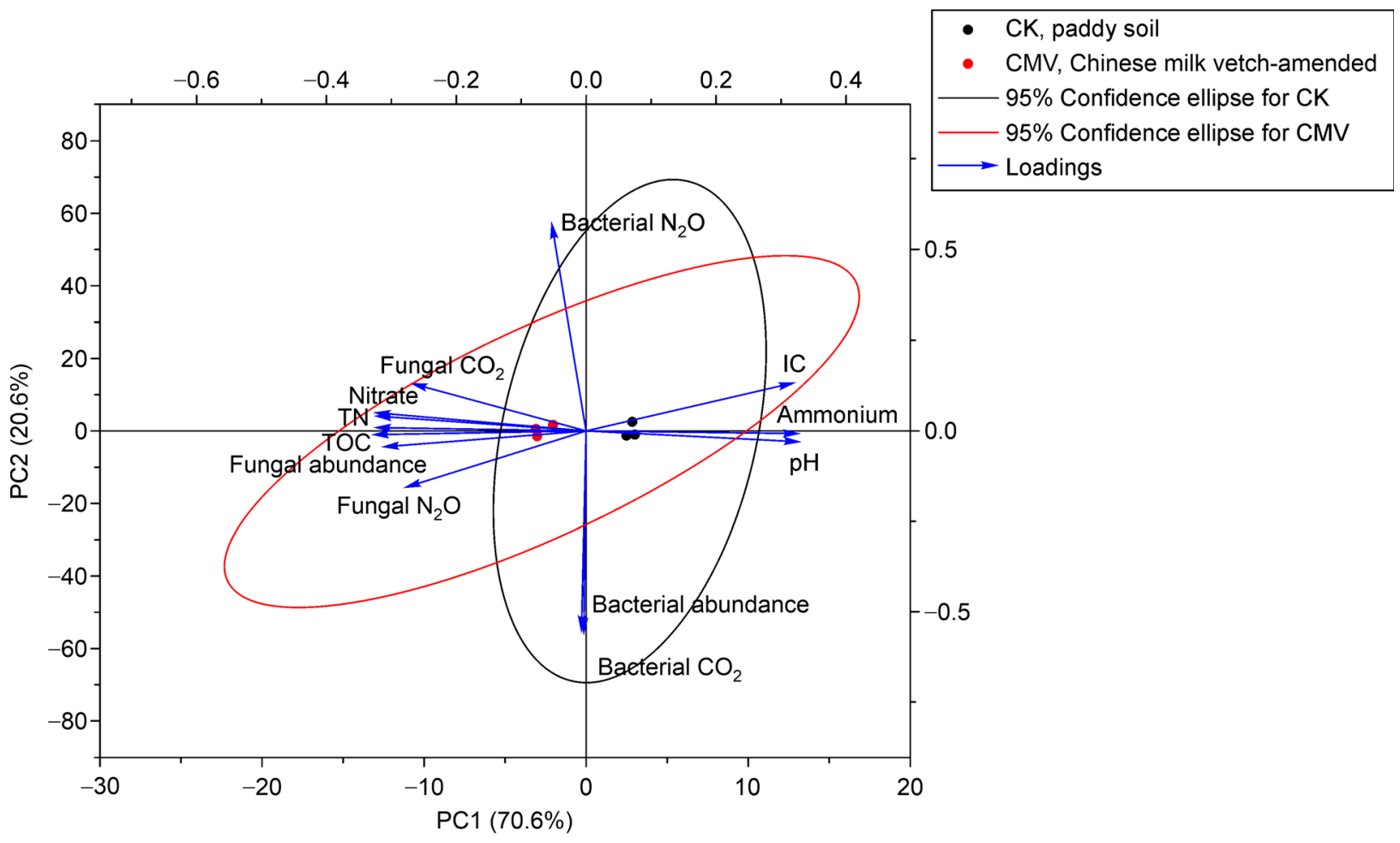

Fig. 4 Relationships among soil properties and nitrous oxide and carbon dioxide emissions based on Principal Component Analysis. Soil attributes are indicated by arrows and treatment groups are indicated by dots.

dominate $\mathrm{N}_{2} \mathrm{O}$ emission in soils with low pH (Rutting et al., 2013). Moreover, soil fungi exhibit growth over a broad range of $\mathrm{pH}$ and the fungal community is only minimally affected by acidic $\mathrm{pH}$ (Rousk et al., 2010). Under low pH conditions, the dominant contribution of fungi to $\mathrm{N}_{2} \mathrm{O}$ production could be related to the primary growth of fungi, which is in agreement with our results (Figs. 4, 5).

The added CMV significantly increased the TOC of the soil, and TOC was positively related to fungal $\mathrm{N}_{2} \mathrm{O}$ emission (Table 1, Fig. 4). Organic matter in the soil was primarily decomposed by fungi and bacteria. Generally, bacteria can utilize simple and regularly supplied $\mathrm{C}$ compounds and fungilike complex compounds, plumbers, and substances (Chen et al., 2015). Compared to bacteria, fungi degrade complex compounds more effectively because they produce extracellular enzymes and allocate a large amount of carbon substrates to enzyme synthesis (de Boer et al., 2005). Microbial activities control the conversion of carbon resources from plant biomass into microbial biomass or $\mathrm{CO}_{2}$ (Liang et al., 2017; Soares and Rousk, 2019). In addition, alterations in the dominance of the microbial community to fungi may increase $\mathrm{C}$ storage in soils, as fungi-dominant soils show lower carbon losses and higher carbon absorptivity rates (Laughlin et al., 2009).

In terms of nitrogen content, we found that CMV increased the concentration of $\mathrm{NO}_{3}{ }^{-}-\mathrm{N}$, reduced the concentration of $\mathrm{NH}_{4}{ }^{+}-\mathrm{N}$, and $\mathrm{NH}_{4}{ }^{+}-\mathrm{N}$ was converted to $\mathrm{NO}_{3}{ }^{-}-\mathrm{N}$ through the activity of microbes. Fungi can oxidize $\mathrm{NH}_{4}{ }^{+}$and organic $\mathrm{N}$ (Laughlin et al., 2008) and may have a latent ability to obtain
$\mathrm{NH}_{4}{ }^{+}$. Moreover, archaea are the primary microorganisms that oxidize $\mathrm{NH}_{4}{ }^{+}$in some terrestrial ecosystems (Laughlin et al., 2008). In our experiment, neither streptomycin nor cycloheximide (microbial inhibitor) inhibited archaea. The conversion of $\mathrm{NH}_{4}{ }^{+}$to $\mathrm{NO}_{3}{ }^{-}$could also be related to archaeal activity. In addition, archaea activity might explain why neither streptomycin nor cycloheximide inhibited $\mathrm{N}_{2} \mathrm{O}$ emission in our experiment (Fig. 1).

Bacterial growth can be increased in the soil by adding plant materials with low $\mathrm{C} / \mathrm{N}$ ratios, whereas fungal dominance occurs when plant materials with high $\mathrm{C} / \mathrm{N}$ ratios are added (Thiet et al., 2006). However, in our experiments, we found that CMV significantly increased the $F$ to $B$ ratio, which agrees with the results of Chen et al. (2019). They showed that CMV considerably increased soil organic carbon, increasing soil aggregation. Greater aggregation often creates more pores, particularly those large in size, thereby creating a favorable environment for the growth of fungal hyphae (Zhang et al., 2015). We conducted incubation in an $80 \%$ water-filled pore space, which was not an optimal environment for bacterial $\mathrm{N}_{2} \mathrm{O}$ production under strict anaerobic circumstances, and fungi dominated under sub-anoxic conditions (Bouwman, 1998). The qPCR results indicated that CMV increased microbial growth, particularly fungal growth, and led to a high fungi-to-bacteria ratio. Direct positive effects were also observed between the fungal abundance and fungi-tobacteria ratios and $\mathrm{N}_{2} \mathrm{O}$ production (Figs. 4 and 5). A previous study showed that fungal and bacterial contributions to $\mathrm{N}_{2} \mathrm{O}$ fluxes could be deduced from their ratio in a microbial 


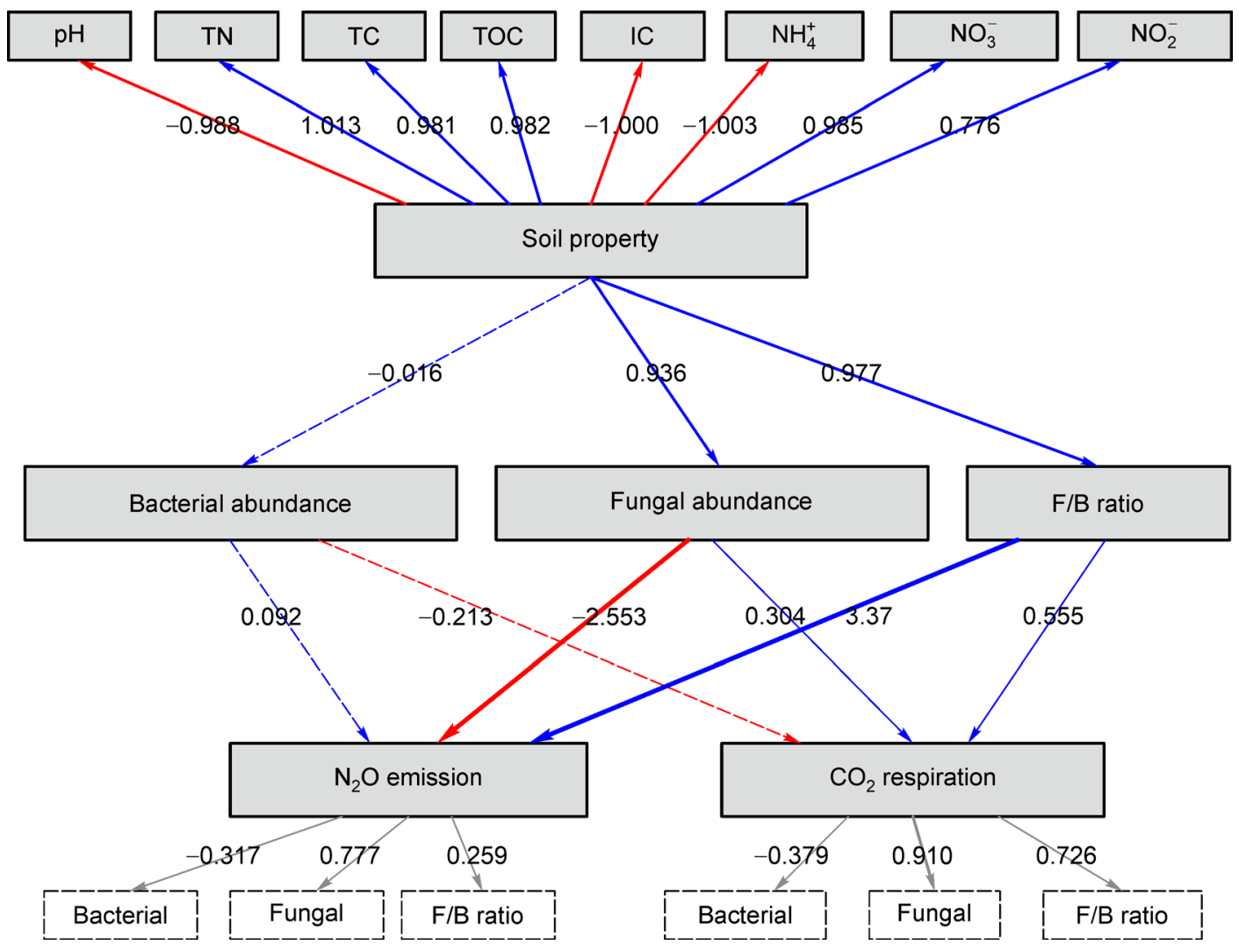

Fig. 5 Path analysis of microbial abundance in relation to nitrous oxide $\left(\mathrm{N}_{2} \mathrm{O}\right)$ emission, carbon dioxide $\left(\mathrm{CO}_{2}\right)$ respiration, and soil properties. Each box represents a variable: measured or constructs. The fungal and bacterial contribution to $\mathrm{N}_{2} \mathrm{O}$ fluxes and $\mathrm{CO}_{2}$ respiration were used to create the variables and are shown in the dashed rectangle. Path coefficients are reflected by the width of the arrow. The blue and red colors indicate positive and negative effects, respectively. Dashed arrows indicate that coefficients did not differ significantly $(P>0.05)$.

community. Fungi contribute more to soil $\mathrm{N}_{2} \mathrm{O}$ production in no-till systems than in tilled systems, possibly because tillage significantly reduces the fungal biomass (Kinney et al., 2004; Crenshaw et al., 2008; Chen et al., 2014).

\subsection{Methodological considerations}

Experiments focused on fungal and bacterial contributions to soil $\mathrm{N}_{2} \mathrm{O}$ fluxes were conducted based on the SIR inhibition method. One limitation of this method is that the antibiotics do not inhibit $100 \%$ of the intended organisms when the concentrations are not appropriate or non-target organisms may be inhibited (Badalucco et al., 1994). In addition, the total individual effects should be equivalent to the combined effects of both antibiotics (Beare et al., 1990). In this study, the total individual effects were equal to the combined effects of both antibiotics used for evaluating $\mathrm{N}_{2} \mathrm{O}$ emission and $\mathrm{CO}_{2}$ respiration (Fig. 2). The IAR results suggested that the two antibiotics were selective at the concentrations used in the experiment. Moreover, the antibiotics did not inhibit archaea, which are important in denitrification: archaea are common in soil systems and play an important role in denitrification (Cabello et al., 2004), likely exerting important functions in soil $\mathrm{N}_{2} \mathrm{O}$ emission (Butterbach-Bahl et al., 2013). This might explain why combined cycloheximide and streptomycin treatment resulted in slightly higher $\mathrm{N}_{2} \mathrm{O}$ emissions than those observed with treatment using each antibiotic alone.

TN losses from the soil included $\mathrm{N}_{2} \mathrm{O}$ and $\mathrm{N}_{2}$, whereas bacterial denitrifiers reduced $\mathrm{N}_{2} \mathrm{O}$ to $\mathrm{N}_{2}$ and fungi could not reduce $\mathrm{N}_{2} \mathrm{O}$ because of the lack of $\mathrm{N}_{2} \mathrm{O}$ reductase (Zumft, 1997). This difference in physiology leads to concerns regarding whether the estimate of the contribution to soil $\mathrm{N}_{2} \mathrm{O}$ is reliable between bacteria and fungi when performing antibiotic inhibition. The fungal contribution to $\mathrm{N}_{2} \mathrm{O}$ fluxes in streptomycin-added soils may have been overvalued compared with that in antibiotic-free soils. Hence, the contribution of bacteria to $\mathrm{N}_{2} \mathrm{O}$ production could also have been underestimated. Glucose addition can increase the levels of electron donors and enhance bacterial $\mathrm{N}_{2} \mathrm{O}$ reduction (Chen et al., 2014), leading to a more severe underestimation of the ratio of bacterial $\mathrm{N}_{2} \mathrm{O}$ reduction. In contrast, fungal $\mathrm{N}_{2} \mathrm{O}$ fluxes were inhibited in cycloheximide-amended soils and the bacterial production of $\mathrm{N}_{2} \mathrm{O}$ was lower than that in antibioticfree soils. This led to overestimating the contribution of fungal $\mathrm{N}_{2} \mathrm{O}$ fluxes in the soil. Thus, comparing the two soil systems should provide valid results, and fungi contribute more to $\mathrm{N}_{2} \mathrm{O}$ flux in CMV-amended soils. 


\section{Conclusions}

Through selective antibiotic inhibition, we demonstrated that fungi strongly contribute to soil $\mathrm{N}_{2} \mathrm{O}$ emission in CMVamended soils. CMV is generally used as green manure in the south of China, and the determination of the flux of $\mathrm{N}_{2} \mathrm{O}$ from this soil may have important implications. Models that are currently used to predict soil $\mathrm{N}_{2} \mathrm{O}$ discharge are primarily based on studies of bacterial denitrification. Thus, mitigation strategies, such as using natural or synthetic nitrification inhibitors (Zhong et al., 2018), targeting bacterial but not fungal $\mathrm{N}_{2} \mathrm{O}$-producing microbes may be useful. Furthermore, fungal denitrifiers often lack $\mathrm{N}_{2} \mathrm{O}$ reductase, leading to high $\mathrm{N}_{2} \mathrm{O}$ production. Whether or not CMV promotes fungal pathways can be inferred from the abundance and composition of fungi and bacteria. Moreover, fungal and bacterial abundance and diversity can be used to manage $\mathrm{N}_{2} \mathrm{O}$ emission in CMV-amended soils.

\section{Acknowledgments}

The research was funded by the National Natural Science Foundation of China (Project No. 31600425). We also thank Fujian Academy of Agricultural Sciences for providing the soil samples for our analysis.

\section{References}

Ai, C., Liang, G., Wang, X., Sun, J., He, P., Zhou, W., 2017. A distinctive root-inhabiting denitrifying community with high $\mathrm{N}_{2} \mathrm{O}$ / $\left(\mathrm{N}_{2} \mathrm{O}^{+} \mathrm{N}_{2}\right)$ product ratio. Soil Biology \& Biochemistry 109, 118-123.

Anderson, J.P.E., Domsch, K.H., 1973. Quantification of bacterial and fungal contributions to soil respiration. Archives of Microbiology 93, 113-127.

Badalucco, L., Pomare, F., Grego, S., Landi, L., Nannipieri, P., 1994. Activity and degradation of streptomycin and cycloheximide in soil. Biology and Fertility of Soils 18, 334-340.

Baggs, E.M., Smales, C.L., Bateman, E.J., 2010. Changing pH shifts the microbial sourceas well as the magnitude of $\mathrm{N}_{2} \mathrm{O}$ emission from soil. Biology and Fertility of Soils 46, 793-805.

Beare, M.H., Neely, C.L., Coleman, D.C., Hargrove, W.L., 1990. A substrate-induced respiration (SIR) method for measurement of fungal and bacterial biomass on plant residues. Soil Biology \& Biochemistry 22, 585-594.

Bolan, N., Hedley, M., White, R., 1991. Processes of soil acidification during nitrogen cycling with emphasis on legume based pastures. Plant and Soil 134, 53-63.

Bouwman, A., 1998. Environmental science: Nitrogen oxides and tropical agriculture. Nature 392, 866-867.

Butterbach-Bahl, K., Baggs, E.M., Dannenmann, M., Kiese, R., Zechmeister-Boltenstern, S., 2013. Nitrous oxide emissions from soils: how well do we understand the processes and their controls? Philosophical Transactions of the Royl Society B, Biological Sciences 368, 20130122

Cabello, P., Roldan, M.D., Moreno-Vivian, C., 2004. Nitrate reduction and the nitrogen cycle in archaea. Microbiol-Sgm 150, 3527-3546.

Chen, H., Mothapo, N.V., Shi, W., 2014. The significant contribution of fungi to soil $\mathrm{N}_{2} \mathrm{O}$ production across diverse ecosystems. Applied Soil Ecology 73, 70-77.

Chen, H.H., Mothapo, N.V., Shi, W., 2015. Fungal and bacterial $\mathrm{N}_{2} \mathrm{O}$ production regulated by soil amendments of simple and complex substrates. Soil Biology \& Biochemistry 84, 116-126.

Chen, Y.F., Hu, N., Zhang, Q.Z., Lou, Y.L., Li, Z.F., Tang, Z., Kuzyakov, Y., Wang, Y.D., 2019. Impacts of green manure amendment on detritus micro-food web in a double-rice cropping system. Applied Soil Ecology 138, 32-36.

Crenshaw, C.L., Lauber, C., Sinsabaugh, R.L., Stavely, L.K., 2008. Fungal control of nitrous oxide production in semiarid grassland. Biogeochemistry 87, 17-27.

Davidson, E.A., 1991. Fluxes of nitrous oxide and nitric oxide from terrestrial ecosystems. In: Rogers, J.E., Whitman, W.B., eds. Microbial Production and Consumption of Greenhouse Gases: Methane, Nitrogen Oxides, and halomethanes, American Society for Microbiology, Washington, DC, pp. 219-235.

Davidson, E.A., Kanter, D., 2014. Inventories and scenarios of nitrous oxide emissions. Environmental Research Letters 9, 105012.

de Boer, W., Folman, L.B., Summerbell, R.C., Boddy, L., 2005. Living in a fungal world: impact of fungi on soil bacterial niche development. FEMS Microbiology Reviews 29, 795-811.

Dolling, P., 1995. Effect of lupins and location on soil acidification rates. Australian Journal of Experimental Agriculture 35, 753-763.

Hadas, A., Kautsky, L., Goek, M., Kara, E.E., 2004. Rates of decomposition of plant residues and available nitrogen in soil, related to residue composition through simulation of carbon and nitrogen turnover. Soil Biology \& Biochemistry 36, 255-266.

Hoben, J.P., Gehl, R.J., Millar, N., Grace, P.R., Robertson, G.P., 2011. Nonlinear nitrous oxide $\left(\mathrm{N}_{2} \mathrm{O}\right)$ response to nitrogen fertilizer in onfarm corn crops of the US Midwest. Global Change Biolology. 17, 1140-1152.

Hu, H.W., Zhang, L.M., Dai, Y., Di, H.J., He, J.Z., 2013. pH-dependent distribution of soil ammonia oxidizers across a large geographical scale as revealed by high-throughput pyrosequencing. Journal of Soils and Sediments 13, 1439-1449.

Huang, Y., Xiao, X., Long, X., 2017. Fungal denitrification contributes significantly to $\mathrm{N}_{2} \mathrm{O}$ production in a highly acidic tea soil. Journal of Soils and Sediments 17, 1599-1606.

Jirout, J., Šimek, M., Elhottová, D., 2013. Fungal contribution to nitrous oxide emissions from cattle impacted soils. Chemosphere 90, 565-572.

Khalil, M., Baggs, E., 2005. $\mathrm{CH}_{4}$ oxidation and $\mathrm{N}_{2} \mathrm{O}$ emissions at varied soil water-filled pore spaces and headspace $\mathrm{CH}_{4}$ concentrations. Soil Biology \& Biochemistry 37, 1785-1794.

Kinney, C.A., Mosier, A.R., Ferrer, I., Furlong, E.T., Mandernack, K.W., 2004. Effects of the fungicides mancozeb and chlorothalonil on fluxes of $\mathrm{CO}_{2}, \mathrm{~N}_{2} \mathrm{O}$, and $\mathrm{CH}_{4}$ in a fertilized Colorado grassland soil. Journal of Geophysical Research. Atmospheres109, D05303.

Lassey, K., Harvey, M., 2007. Nitrous oxide: the serious side of laughing gas. Water Atmos 15, 10-11.

Laughlin, R.J., Rutting, T., Mueller, C., Watson, C.J., Stevens, R.J., 2009. Effect of acetate on soil respiration, $\mathrm{N}_{2} \mathrm{O}$ emissions and gross $\mathrm{N}$ transformations related to fungi and bacteria in a 
grassland soil. Applied Soil Ecology 42, 25-30.

Laughlin, R.J., Stevens, R.J., 2002. Evidence for fungal dominance of denitrification and codenitrification in a grassland soil. Soil Science Society of America Journal 66, 1540-1548.

Laughlin, R.J., Stevens, R.J., Muller, C., Watson, C.J., 2008. Evidence that fungi can oxidize $\mathrm{NH}_{4}{ }^{+}$to $\mathrm{NO}_{3}{ }^{-}$in a grassland soil. European Journal of Soil Science 59, 285-291.

Liang, C., Schimel, J.P., Jastrow, J.D., 2017. The importance of anabolism in microbial control over soil carbon storage. Nature Microbiology 2, 2.

McNeill, A.M., Zhu, C., Fillery, I.R., 1997. Use of in situ ${ }^{15} \mathrm{~N}$-labelling to estimate the total below-ground nitrogen of pasture legumes in intact soil-plant systems. Australian Journal of Agricultural Research 48, 295-304.

Mothapo, N., Chen, H., Cubeta, M.A., Grossman, J.M., Fuller, F., Shi, W., 2015. Phylogenetic, taxonomic and functional diversity of fungal denitrifiers and associated $\mathrm{N}_{2} \mathrm{O}$ production efficacy. Soil Biology \& Biochemistry 83, 160-175.

Mothapo, N.V., Chen, H.H., Cubeta, M.A., Shi, W., 2013. Nitrous oxide producing activity of diverse fungi from distinct agroecosystems. Soil Biology \& Biochemistry 66, 94-101.

Noble, A., Zenneck, I., Randall, P., 1996. Leaf litter ash alkalinity and neutralisation of soil acidity. Plant and Soil 179, 293-302.

Poll, C., Marhan, S., Ingwersen, J., Kandeler, E., 2008. Dynamics of litter carbon turnover and microbial abundance in a rye detritusphere. Soil Biology \& Biochemistry 40, 1306-1321.

Ravishankara, A., Daniel, J.S., Portmann, R.W., 2009. Nitrous oxide $\left(\mathrm{N}_{2} \mathrm{O}\right)$ : the dominant ozone-depleting substance emitted in the 21st century. Science 326, 123-125.

Rousk, J., Baath, E., Brookes, P.C., Lauber, C.L., Lozupone, C., Caporaso, J.G., Knight, R., Fierer, N., 2010. Soil bacterial and fungal communities across a $\mathrm{pH}$ gradient in an arable soil. ISME Journal 4, 1340-1351.

Rutting, T., Huygens, D., Boeckx, P., Staelens, J., Klemedtsson, L., 2013. Increased fungal dominance in $\mathrm{N}_{2} \mathrm{O}$ emission hotspots along a natural $\mathrm{pH}$ gradient in organic forest soil. Biology and Fertility of Soils 49, 715-721.

Soares, M., Rousk, J., 2019. Microbial growth and carbon use efficiency in soil: Links to fungal-bacterial dominance, SOC-quality and stoichiometry. Soil Biology \& Biochemistry 131, 195-205.

Tang, C., Yu, Q., 1999. Impact of chemical composition of legume residues and initial soil $\mathrm{pH}$ on $\mathrm{pH}$ change of a soil after residue incorporation. Plant and Soil 215, 29-38.

Thiet, R.K., Frey, S.D., Six, J., 2006. Do growth yield efficiencies differ between soil microbial communities differing in fungal: bacterial ratios? Reality check and methodological issues. Soil Biology \& Biochemistry 38, 837-844.

Thomson, A.J., Giannopoulos, G., Pretty, J., Baggs, E.M., Richardson, D.J., 2012. Biological sources and sinks of nitrous oxide and strategies to mitigate emissions. Philosophical Transactions of the Royal Society B 367, 1157-1168.

Van den Heuvel, R.N., Bakker, S.E., Jetten, M.S.M., Hefting, M.M., 2011. Decreased $\mathrm{N}_{2} \mathrm{O}$ reduction by low soil pH causes high $\mathrm{N}_{2} \mathrm{O}$ emissions in a riparian ecosystem. Geobiology 9, 294-300.

Wang, Y.F., Tang, C.X., Wu, J.J., Liu, X.M., Xu, J.M., 2013. Impact of organic matter addition on $\mathrm{pH}$ change of paddy soils. Journal of Soils and Sediments 13, 12-23.

Xie, Z.J., Zhou, C.H., Shah, F., lqbal, A., Ni, G.R., 2018. The role of Chinese Milk Vetch as cover crop in complex soil nitrogen dynamics in rice rotation system of South China. Scientific reports 8,12061

Xu, J.M., Tang, C., Chen, Z.L., 2006a. Chemical composition controls residue decomposition in soils differing in initial $\mathrm{pH}$. Soil Biology \& Biochemistry 38, 544-552.

Xu, J.M., Tang, C., Chen, Z.L., 2006b. The role of plant residues in $\mathrm{pH}$ change of acid soils differing in initial pH. Soil Biology \& Biochemistry 38, 709-719.

Xu, R.K., Coventry, D.R., 2003. Soil pH changes associated with lupin and wheat plant materials incorporated in a red-brown earth soil. Plant and Soil 250, 113-119.

Yanai, Y., Toyota, K., Morishita, T., Takakai, F., Hatano, R., Limin, S.H., Darung, U., Dohong, S., 2007. Fungal $\mathrm{N}_{2} \mathrm{O}$ production in an arable peat soil in Central Kalimantan, Indonesia. Soil Science and Plant Nutrition 53, 806-811.

Yang, Z.P., Zheng, S.X., Nie, J., Liao, Y.L., Xie, J., 2014. Effects of long-term winter planted green manure on distribution and storage of organic carbon and nitrogen in water-stable aggregates of reddish paddy soil under a double-rice cropping system. Journal of Integrative Agriculture 13, 1772-1781.

Zhang, L., Jiang, M., Ding, K., Zhou, S., 2019. Iron oxides affect denitrifying bacterial communities with the nirS and nirK genes and potential $\mathrm{N}_{2} \mathrm{O}$ emission rates from paddy soil. European Journal of Soil Biology 93, 103093.

Zhang, X., Guan, P., Wang, Y., Li, Q., Zhang, S., Zhang, Z., Bezemer, T.M., Liang, W., 2015. Community composition, diversity and metabolic footprints of soil nematodes in differently-aged temperate forests. Soil Biology \& Biochemistry 80, 118-126.

Zhao, S.C., Qiu, S.J., Xu, X.P., Ciampitti, I.A., Zhang, S.Q., He, P., 2019. Change in straw decomposition rate and soil microbial community composition after straw addition in different long-term fertilization soils. Applied Soil Ecology 138, 123-133.

Zhong, L., Bowatte, S., Newton, P.C.D., Hoogendoorn, C.J., Luo, D. W., 2018. An increased ratio of fungi to bacteria indicates greater potential for $\mathrm{N}_{2} \mathrm{O}$ production in a grazed grassland exposed to elevated $\mathrm{CO}_{2}$. Agriculture, Ecosystems \& Environment 254, $111-$ 116.

Zumft, W.G., 1997. Cell biology and molecular basis of denitrification. Microbiology and Molecular Biology Reviews 61, 533-616. 